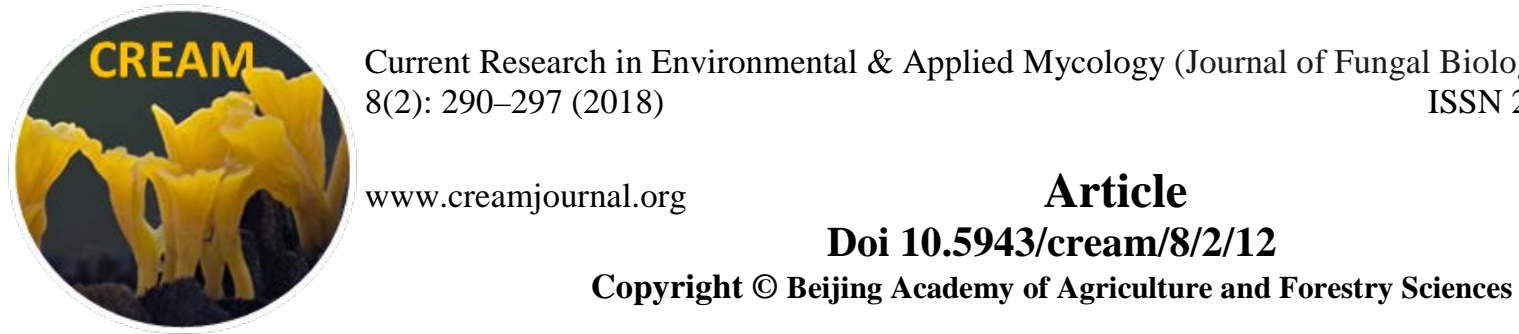

\title{
Mycodegradation of reed straw, Phragmites australis
}

\author{
Owaid MN ${ }^{1, *}$, Muslat $\mathrm{MM}^{2}$, Abed IA ${ }^{3}$ \\ ${ }^{1}$ Department of Heet Education, General Directorate of Education in Anbar, Ministry of Education, Hit, Anbar 31007, \\ Iraq \\ ${ }^{2}$ Department of Horticulture, College of Agriculture, University of Anbar, Ramadi, Anbar 31001, Iraq \\ ${ }^{3}$ Desert Studies Center, the University Campus, University of Anbar, Ramadi, Anbar 31001, Iraq
}

Owaid MN, Muslat MM, Abed IA 2018 - Mycodegradation of reed straw, Phragmites australis. Current Research in Environmental \& Applied Mycology (Journal of Fungal Biology) 8(2), 290297, Doi 10.5943/cream/8/2/12

\begin{abstract}
The reed plant (Phragmites australis) is available as an economical alternative to wheat straw, when the last substrate is unavailable or has a high price, to apply it in the preparing compost for the cultivation of white button mushroom Agaricus bisporus X25. Reed straw compost recorded the best total yield (441 g/tray) compared with $371 \mathrm{~g} /$ tray by the wheat straw compost (control). Also, use of Actinomycetes Streptomyces sp. in the biodegradation processes of compost, lead to increase the total yield of A. bisporus X25 to $430 \mathrm{~g} /$ tray compared with the microbiologically nontreated composts (376 g/tray), after 21 days from primordia appearance significantly $(p<0.05)$. Quality and size of fruiting bodies were varied from compost to another one depended on diameter of cap (pileus) and length of stipe. The more significant diameter had been recorded $56 \mathrm{~mm}$ for fruits on reed straw compost while the lower diameter was $42 \mathrm{~mm}$ on fruits of the control compost (wheat straw compost).
\end{abstract}

Key words - Agaricus bisporus - agricultural wastes - compost - mushroom - Streptomyces sp.

\section{Introduction}

The white button mushroom Agaricus bisporus, one of the fleshy fungi, belongs to Basidiomycota. A. bisporus has a high nutritive value due to its high protein content compared with Pleurotus sp. (Chang \& Miles 2004). A. bisporus is an edible mushroom that grows upon decomposed organic matters. Generally, mushrooms don't have the ability for using the energy of the sun to produce the carbohydrates in photosynthesis because lacking chlorophylls (Stephens 2003). The first mention of cultivation of mushroom was in 1652 when appeared in the field naturally (Beyer 2003). The potential of bioconversion of lignocellulosic wastes into value-added products was tested in last studies such as production of fresh fruits, feed of ruminants and production of enzymes (Zervakisn \& Philippoussis 2000). A. bisporus can be grown on wheat straw (Baysal et al. 2007), sawdust mixed with wheat straw (Schmidt 2006), waste tea leaves (Simsek et al. 2008), waste paper (Sassine et al. 2007), common reed (Alheeti et al. 2010, Muslat et al. 2011a,b) and sunflower head composts (Muslat et al. 2014).

Medicinally, Hippocrates first referred to the medicinal mushrooms in the treatment in 400 B.C. (Beyer 2003). Extracts of A. bisporus has antibacterial (Tamberkar et al. 2006), antifungal (Atila et al. 2017) antioxidant, and anticancer activities (Roberts et al. 2008). Also it used to treat 
atherosclerosis and diabetes; and to treat obesity because of it has low calories (Halpern 2006). Recently, A. bisporus was used to biosynthesize silver nanoparticles as nano-drugs in so-called Green Chemistry (Atila et al. 2017). A bisporus has some useful mineral elements such as $\mathrm{Na}, \mathrm{K}$, $\mathrm{Pb}, \mathrm{Co}, \mathrm{Fe}, \mathrm{Cr}, \mathrm{Cu}, \mathrm{Ni}, \mathrm{Zn}, \mathrm{Mn}$ and $\mathrm{Cd}$ which encourage the citizens for consuming it as a healthy food (Owaid 2015). Also, it contains elemental P, S, Ca and Li, without starch, rich of essential vitamins A, B, C, and D (USDA 2011) and essential amino acids (Muslat et al. 2014).

The genus Streptomyces is one of the most genera of Actinomycetes in soil; it belongs to the family Streptomycetaceae and order Actinomycetales. It is filament bacteria, aerobic and Grampositive bacteria (Locci 1989). The bacteria Streptomyces spp. has a wide distribution in the various environments (soil, water, and air). But the soil is a major source of this bacterium (David \& Sheare 1988). Also, it finds in other ecological media such as organic fertilizers, manure, and plant residues. The warm places are adequate to grow huge biomass of this bacterium; also the organic matters are a useful and a necessary factor in developing this microorganism (Motr 2009). This bacterium is capable to degrade the simple forms of cellulose and produce its biomsss which is considered as nitrogen source for mycelial of mushroom later (Muslat et al. 2014). Thus this bacterium was used to decompose composts in this work to raise the total yield of A. bisporus X25 after treatment of those composts by Actinomycetes in a low cost and an eco-friendly method.

\section{Materials \& Methods}

\section{Microbial strain}

The spawn of white button mushroom Agaricus bisporus X25 was obtained from Le Lion Company, France by the Hameediyah Mushroom Farm (HMF), Ramadi, Kilo 18, Iraq. The bacterium Streptomyces sp. (strain O3) obtained from Department of Biology, College of Science, University of Anbar, Iraq which isolated from Ramadi soils, Iraq. This bacterium was used as bioagent to biodegrade of media at concentration $10^{6} \mathrm{cfu}$ (cells) $/ \mathrm{kg}$ of dry matter during the composting process.

\section{Preparing inoculum of Streptomyces sp.}

The bacterium Streptomyces sp. is maintained using Gauze's Agar medium (GAM) which constituents of $20 \mathrm{~g}$ soluble starch, $1 \mathrm{~g} \mathrm{KNO}_{3}, 0.5 \mathrm{~g} \mathrm{NaCl}, 0.5 \mathrm{~g} \mathrm{MgSO}_{4} .7 \mathrm{H}_{2} \mathrm{O}, 0.5 \mathrm{~g} \mathrm{~K}_{2} \mathrm{HPO}_{4}$ and $0.001 \mathrm{~g} \mathrm{FeSO}_{4} .5 \mathrm{H}_{2} \mathrm{O}$ which dissolved in $1 \mathrm{~L}$ of the tap water. The $\mathrm{pH}$ of GAM was adjusted to 7.27.4, agar 15 g added, dissolved and autoclaved (Motr 2009). The Nutrient Broth is used to prepare the Streptomyces inoculum at the concentration $10^{6} \mathrm{CFU} / \mathrm{ml}$ and applied $\mathrm{ml} / \mathrm{kg}$ of dry matter.

\section{Preparing compost, composting, pasteurization and the Cultivation of $A$. bisporus X25}

Below, details of each formula which obtained from local gardens in Heet district, Iraq. The principal lignocellulosic matters are formed from wheat (Triticum sativum) straw, reed (Phragmites australis) straw. Six treatments were used in this test including A: wheat straw compost, B: reed straw compost, C: the mixture compost (1:1), AS: the decomposed wheat straw compost using Streptomyces sp., BS: the decomposed reed straw compost using Streptomyces sp., CS: the decomposed mixture compost using Streptomyces sp., see Table 1.

Solid state fermentation was achieved outdoor and indoor during phase 1 and phase 2 respectively as mentioned by Owaid (2009). After pasteurization of compost and cooling, mushroom spawn was applied within bed at percent 2\% based on dry weight using Ruffling Method until mycelial growth completion. Pasteurizing the casing layer (consisted of peat moss and soil) was applied using formalin at concentration $500 \mathrm{ppm}$. Other processes were used as mentioned by Owaid (2009). Casing layer was used in-depth $2.5 \mathrm{~cm}$ as mentioned by Royse (2008). At $18-16{ }^{\circ} \mathrm{C}$ temperature and $90 \%$ relative humidity, some determinations of this mushroom were calculated using six replications. The total yield of A. bisporus X25 for the period 21 days after primordia appearance, biological efficiency, number of fruiting bodies, diameter of cap, length of 
stipe and the ratio of diameter of cap to length of stipe were determined in six composts with or without decomposition using bacterium Streptomyces sp.

Table 1 Properties and compositions of composts of Agaricus bisporus X25 in this work

\begin{tabular}{lcccccc}
\hline Materials (kg) & A & B & C & AS & BS & CS \\
\hline Wheat straw & 50 & - & 25 & 50 & - & 25 \\
Reed straw & - & 50 & 25 & - & 50 & 25 \\
Chicken manure & 41.2 & 41.2 & 41.2 & 41.2 & 41.2 & 41.2 \\
Urea & 2.47 & 2.47 & 2.47 & 2.47 & 2.47 & 2.47 \\
Gypsum & 6.33 & 6.33 & 6.33 & 6.33 & 6.33 & 6.33 \\
Streptomyces sp. applying & - & - & - & Yes & Yes & Yes \\
\hline
\end{tabular}

\section{Statistical Analysis}

Statistical significance was determined using CRD (two ways) analysis of variance (ANOVA) by applying GenStat program (VSN International Ltd., UK). Significant differences at $p<0.05$ were considered. All the experiments were done in six replicates.

\section{Results}

Influence of the treatments (type of compost and using Streptomyces or no) on the crop of Agaricus bisporus X25 was reported and discussed in this study. The treated reed straw compost using Streptomyces sp. (BS) showed higher total yield (496 g/tray) significantly ( $p<0.05$ ), followed 400, 397 and 396 g/tray for C, AS and CS composts respectively, compared with the lower total yield which showed on wheat straw compost (control, A) (344 g/tray) in this work (Table 2). The best biological efficiency was $29.3 \%$ on the decomposed reed straw compost using Streptomyces bacterium (BS), followed by $28.8 \%$ and $25.1 \%$ on AS and C composts respectively. But, the lower biological efficiency was $20.8 \%$ on CS compost compared with $22.7 \%$ by the control (A). The higher fruits number was observed 18 fruits on the treated wheat straw compost using Streptomyces (AS) compared with 17 fruits by the control (wheat straw compost, A) significantly $(p<0.05)$. The lower number was 7 fruits on the reed straw compost (B) which increased to 8 fruits when using bacteria in the decomposing process (BS compost).

Quality and size of fruiting bodies were varied from compost to another one depended on the diameter of cap (pileus) and the length of stipe. The biggest diameter had been recorded on fruits of reed straw compost (B) $56 \mathrm{~mm}$, while the smaller diameter was $42 \mathrm{~mm}$ for the fruits on the control compost (A). The bigger length was $34 \mathrm{~mm}$ on fruits of the treated wheat straw compost using Streptomyces (AS) compared with the control $(29 \mathrm{~mm})$ as a lower value (Table 2). The higher ratio of diameter of cap to the length of stipe (DC/LS ratio) was 1.8 on the mixture compost (C) while the lower ratio was 1.2 on the treated wheat straw compost using Streptomyces (AS). DC/LS ratio is useful for the quality of the mushroom when equal or more than 1.

Table 2 Properties of the harvested Agaricus bisporus X25 during 21 days after primordia appearance

\begin{tabular}{lccccccc}
\hline Features & A & B & C & AS & BS & CS & $\begin{array}{c}\text { LSD } \\
(\boldsymbol{p}<\mathbf{0 . 0 5})\end{array}$ \\
\hline Total Yield (g/tray) & 344 & 385 & 400 & 397 & 496 & 396 & 5.8 \\
Biological efficiency (\%) & 22.7 & 23.6 & 25.1 & 28.8 & 29.3 & 20.8 & 10.82 \\
No. of Fruiting bodies & 17 & 7 & 9 & 18 & 8 & 10 & 0.9 \\
Diameter of cap (mm) & 42 & 56 & 55 & 43 & 55 & 50 & 2.5 \\
Length of stipe (mm) & 29 & 32 & 29 & 34 & 30 & 28 & 1.7 \\
DC/LS ratio & 1.4 & 1.7 & 1.8 & 1.2 & 1.8 & 1.7 & 0.11 \\
\hline
\end{tabular}

Legend: Tray: (5 kg based on wet matter), DC/LS ratio: diameter of cap to length of stipe ratio. A: wheat straw compost, B: reed straw compost, C: the mixture compost (1:1), AS: the decomposed wheat straw 
compost using Streptomyces, BS: the decomposed reed straw compost using Streptomyces, CS: the decomposed mixture compost using Streptomyces.

Effect of the organic source and using Streptomyces sp. bacterium on the cultivation of $A$. bisporus X25 was tested and recorded. The compost type or the carbon source has a significant $(p<0.05)$ influence on most properties of Agaricus bisporus X25 as shown in Table 3. The reed straw compost showed the best total yield $441 \mathrm{~g} /$ tray then it decreased to $398 \mathrm{~g}$ /tray on the mixture compost 1:1 in comparison with the control (wheat straw compost) which reached $371 \mathrm{~g} /$ tray. The biological efficiency of wheat straw and reed straw composts reached $26 \%$ without any effects. The more significant fruits number has recorded 18 fruiting bodies on the wheat straw compost, significantly $(p<0.05)$, compared with other composts. The reed straw compost has only eight fruits and significant cap's diameter reached $56 \mathrm{~mm}$. The length of stipe was approx. $31 \mathrm{~mm}$ as average but the ratio of the diameter of cap to the length of stipe (DC/LS ratio) was more than one on all composts.

Table 3 Effect of using Streptomyces sp. on properties of the harvested A. bisporus

\begin{tabular}{lcccccr}
\hline Treatments & $\begin{array}{l}\text { Total } \\
\text { yield } \\
\text { (g/tray) }\end{array}$ & $\begin{array}{l}\text { Biological } \\
\text { efficiency } \\
\text { \% }\end{array}$ & $\begin{array}{l}\text { Fruit } \\
\text { bodies } \\
\text { No. }\end{array}$ & $\begin{array}{l}\text { Diameter } \\
\text { of cap } \\
\text { (mm) }\end{array}$ & $\begin{array}{l}\text { Length } \\
\text { of stipe } \\
\text { (mm) }\end{array}$ & \multicolumn{1}{l}{$\begin{array}{l}\text { DS/LS } \\
\text { ratio }\end{array}$} \\
\hline Wheat straw compost & 371 & 26 & 18 & 43 & 32 & 1.30 \\
Reed straw compost & 441 & 26 & 8 & 56 & 31 & 1.75 \\
The mixture compost 1:1 & 398 & 23 & 10 & 53 & 29 & 1.75 \\
LSD $(p<0.05)$ & 4.1 & 7.6 & 0.6 & 1.8 & 1.2 & 0.083 \\
\hline
\end{tabular}

Legend: Tray: $5 \mathrm{~kg}$ based on wet matter, DC/LS ratio: diameter of cap to length of stipe ratio.

Significantly, $(p<0.05)$, using Streptomyces sp. bacterium led to increase the total yield of fresh Agaricus bisporus X25 after 21 days from primordia appearance that reached $430 \mathrm{~g} /$ tray $(5 \mathrm{~kg}$ compost based on wet matter) compared with the microbiologically non-treated composts (376 $\mathrm{g}$ /tray), see Table 4. Also, the previous table showed the biological efficiency of A. bisporus X25 cultivated on the microbiologically treated composts. The treated composts using Streptomyces gave a biological efficiency of $26 \%$ compared with the non-treated compost of $24 \%$. Using bacteria led to increase the number of fruiting bodies to 12 fruits significantly $(p<0.05)$, compared with 11 fruiting bodies on the microbiologically non-treated composts. Quality and size of fruiting bodies were varied from compost to another one depending on the diameter of cap (pileus), the length of stipe and the ratio of the diameter of cap to the length of stipe of fruiting bodies (Table 4). The diameter of cap recorded approx. $50 \mathrm{~mm}$ in this test, generally. Using bacteria in the treatments gives diameter of cap $49 \mathrm{~mm}$ compared with $51 \mathrm{~mm}$ without the biological treatment. Also, using Streptomyces as a decomposer for composts leads to increase the length of stipe to $31 \mathrm{~mm}$ compared with $30 \mathrm{~mm}$ without microbiologically treating. If the ratio of the diameter of cap to the length of stipe of fruiting bodies was more than 1, that meaning it is useful for quality of mushroom.

Table 4 Effect of using Streptomyces sp. on properties of the harvested A. bisporus

\begin{tabular}{lcccccc}
\hline Treatments & $\begin{array}{l}\text { Total } \\
\text { yield } \\
\text { (g/tray) }\end{array}$ & $\begin{array}{l}\text { Biological } \\
\text { efficiency } \\
\text { \% }\end{array}$ & $\begin{array}{l}\text { Fruiting } \\
\text { bodies } \\
\text { No. }\end{array}$ & $\begin{array}{l}\text { Diameter } \\
\text { of cap } \\
\text { (mm) }\end{array}$ & $\begin{array}{l}\text { Length of } \\
\text { stipe } \\
\text { (mm) }\end{array}$ & $\begin{array}{l}\text { DS/LS } \\
\text { ratio }\end{array}$ \\
\hline $\begin{array}{l}\text { Without using the } \\
\text { bacteria }\end{array}$ & 376 & 24 & 11 & 51 & 30 & 1.63 \\
Using the bacteria & 430 & 26 & 12 & 49 & 31 & 1.56 \\
LSD $(p<0.05)$ & 3.3 & 6.2 & 0.5 & 1.4 & 0.9 & 0.068 \\
\hline
\end{tabular}

Legend: Tray: $5 \mathrm{~kg}$ based on wet matter, DC/LS ratio: diameter of cap to length of stipe ratio. 


\section{Discussion}

In this study, biological efficiency depends on total yield after 21 days from primordia appearance as demonstrated by the positive correlation between the total yield and the biological efficiency (Table 5). According to compost weight, the mushroom yield on reed straw compost increased compared with the wheat straw and the mixture composts. The variances in the yield may be returned to difference these composts in their capability in ecological and nutritional requirements because the differences of compositions of composts. Also, the content of cellulose, hemicellulose, and lignin was varied in these composts, which took place in the numerous decomposition levels (Edit et al. 2006). When mushroom yield increased, fruits sizes increased too as seen in Table 5, which demonstrated finding a positive correlation among mushroom characteristics.

Table 5 Correlation among properties of mushroom A. bisporus X25

\begin{tabular}{lcccccc}
\hline \multicolumn{1}{c}{ Correlation } & Total yield & BE & $\begin{array}{c}\text { No. of } \\
\text { Fruits }\end{array}$ & $\begin{array}{c}\text { Diameter } \\
\text { of cap }\end{array}$ & $\begin{array}{c}\text { Length of } \\
\text { stipe }\end{array}$ & $\begin{array}{c}\text { DC/LS } \\
\text { ratio }\end{array}$ \\
\hline BE & 0.483 & 1.000 & & & & \\
No. of Fruits & 0.084 & 0.267 & 1.000 & & & \\
Diameter of cap & 0.153 & -0.155 & -0.865 & 1.000 & & \\
Length of stipe & -0.012 & 0.151 & 0.176 & -0.116 & 1.000 & \\
DC/LS ratio & 0.127 & -0.202 & -0.770 & 0.848 & -0.618 & 1.000 \\
\hline
\end{tabular}

Legend: BE: biological efficiency, DC/LS ratio: diameter of cap to length of stipe ratio.

From another side, type and ratio of constituents of the compost have a useful effect toward production of mushroom, which shows an increasing number of fruiting bodies in the control compost due to finding more of nutrients in wheat straw and the mixture composts compared with the reed compost (Muslat et al. 2011b). All that led to increasing surfaces of compost constituents to occur most biodegradation and formation of fungal biomass. These results made to produce high fruits, sometimes appear in cluster form on casing layer (Aswad 2005). The number of fruiting bodies decreased on the reed straw compost in comparison with wheat straw, and the mixture composts that due to different proportions and constituents of each medium (Owaid 2009).

The reason for the high yield when using Streptomyces sp. in the decomposition process may be returned to the ability of Actinomycetes biomass to give high levels of amino acids that lead to improving agro-media for A. bisporus cultivation (Aswad 2005). Extracts of bacteria also could inhibit the growth of undesirable microorganisms such as green molds Trichoderma sp. and other pathogenic fungi (Fermor \& Grant 1985) because of recording alkaline levels in compost when finding Streptomyces sp. (Muslat et al. 2011a). Streptomyces sp. adjusts $\mathrm{pH}$ of media to alkaline by producing ammonia which helps to precipitate $\mathrm{CaCO}_{3}$. It produces bioactive matters like antibiotics (Adekunle 1985). Likewise, Inbar et al. (2005) referred to produce metabolism byproducts such as antibiotics and extracellular enzymes in compost which has force toward some fungal pathogens.

Streptomyces sp. has critical ecological roles in the decomposition of organic matters such as plant wastes, manure, and organic fertilizers by using keratinase and chitinase as nitrogen and carbon sources (Chigaleichik et al. 1978) and cellulose (Ishaque \& Kluepfel 1980). Motr (2009) used isolated Streptomyces sp. isolated from the soil in the decomposing biotechnology because it is capable of handling and utilizing lignin and cellulosic matters as a carbon source with inhibitory activity against pathogens and undesirable fungi. Streptomyces sp. is useful in increasing yield and essential physiochemical properties of compost by its byproducts and its biomass (Aswad 2005). That agrees with the positive correlation between the nitrogen content in compost and mushroom from the side (Royse 2008), and with results of this experiment from another one. The growth of bacteria especially Streptomyces sp. is essential to growing A. bisporus because of its effects on C:N ratio which leads to induce the primordial formation (Wood 1976, Chen et al. 2013). This bacterium plays a useful role to prevent stay asexual phase of $A$. bisporus and induce fruiting 
bodies formation (Wood 1976). These results agree with findings of Straatsma et al. (1989), Sanchez \& Royse (2008), Zarenejad et al. (2012), they referred for producing a suitable compost for A. bisporus cultivation by using Scytalidium thermophilum and some thermophilic fungi.

\section{References}

Adekunle O. 1985 - A study of the properties of ultraviolet radiation induced mutants of Streptomyces cattleya, using numerical taxonomy techniques for the selection of mutants with improved antibiotic yields. Ph.D. thesis, Surrey Uni. UK.

Alheeti MN, Al-Assaffii IA, Muslat MM. 2010 - Evalution the efficiency of reed plant (Phragmites australis) wastes and aqueous extract of Liquorices (Glycyrrhiza glabra) on the production of Agaricus bisporus. Journal of University of Anbar for Pure Science. 4(2), 1321.

Aswad HB. 2005 - Effect of microbial biotechnological and media mixtures on production of Oyster Mushroom (Pleurotus ostreatus). M.Sc. thesis, College of Agriculture, University of Anbar, Iraq. pp. 78.

Atila F, Owaid MN, Shariati MA. 2017 - The nutritional and medical benefits of Agaricus Bisporus: A review. Journal of Microbiology, Biotechnology and Food Sciences 7(3), pp. 281-286

Baysal E, Yigitbasi ON, Colak M, Toker H et al. 2007 - Cultivation of Agaricus bisporus on Some Compost Formulas and Locally Available Casing Materials. Part 1: Wheat Straw Based Compost Formulas and Locally Available Casing Materials. Afr. J. Biotechnol. 6(1), 22252230.

Beyer DM. 2003 - Basic Procedures for Agaricus Mushroom Growing. Penn State College of Agricultural Sciences Research, Extension, and Resident Education Programs, Pennsylvania, Chester. pp. 16.

Chang ST, Miles PG. 2004 - Mushrooms Cultivation, Nutritional Value, Medicinal Effect and Enviromental Impact, 2nd Ed. CRC Press LLC. USA. pp. 451.

Chen S, Qiu C, Huang T, Zhou W et al. 2013 - Effect of 1-aminocyclopropane-1-carboxylic acid deaminase producing bacteria on the hyphal growth and primordium initiation of Agaricus bisporus. Fungal Ecology. 6, 110-118.

Chigaleichik AG, Shkidchenko AN, Pirieva DA. 1978 - Chilinolytic activity of Actinomyces kurssanovii under conditions of periodic and continuous culturing. Prikl Biokhim Mikrobiol. 14, 412-416.

David P, Sheare CM. 1988 - Isolation of Actinomycetes for biotechnological application (1-29). Northern Regional Research Center. Agricultural Research Service, US, Agriculture Dep., Peoria, Illinois, 61604.

Edit AS, Dinka M, Nemedi L, Horvath G. 2006 - Decompostion of Phragmites australis rhizome in a Shallow Lake. Aquatic Botany. 85, 309-316.

Fermor TR, Grant WD. 1985 - Degradation of Fungal and Actinomycete Mycelia by Agaricus bisporus. J. Gen. Microbiol. 131, 1729-1734.

Halpern GM. 2006 - Healing Mushrooms. Squareone Publishers. USA. pp. 182.

Inbar E, Green SJ, Hadar Y, Minz D. 2005 - Competing factors of compost concentration and proximity to root affect the distribution of Streptomyces. Microbiology Ecology. 50, 73-81.

Ishaque M, Kluepfel D. 1980 - Cellulase complex of a mesophilic Streptomyces flavogriseus strain. Can. J. Microbiol. 26, 183-189.

Locci R. 1989 - Streptomyces and related genera. In: Williams ST, Sharpe ME, Holt JG eds. Bergy's Manual of Systematic Bacteriology. Williams and Wilkins Co., Baltimare. 4, 24512508

Motr TY. 2009 - Test the inhibition activity of two local Streptomyces isolates by used sawdust as a carbone source. Al-Anbar University Journal for Pure Sciences. 2(3), 81-69. 
Muslat MM, Al-Assaffii IA, Alheeti MN. 2011a - A Study of Some Physical and Chemical Characteristics for Compost of Heterogeneous of Cellulose during the Fermentation Period for Mushroom Cultivation of Agaricus bisporus. Al-Anbar Journal of Agricultural Sciences. 9(1), 197-206.

Muslat MM, Al-Assaffii IA, Alheeti MN. 2011b - Use Efficiency of Reed Residues Phragmites australis with Amendment by Streptomyces O3 to Prepared Compost for Agaricus bisporus Production and Influence of Spraying Glycyrrhiza sp. extracts. Research Journal of Aleppo University. Agricultural Science Series. 93, 149-168.

Muslat MM, Al-Assaffii IAA, Owaid MN. 2014 - Agaricus bisporus product development by using local substrate with bio-amendment. International Journal for Environment and Global Climate. 2(4), 176-188.

Owaid MN. 2009 - Biotechnology for local compost preparation used to produce mushroom Agaricus bisporus. M.Sc. thesis. Dep. Biology, College of Science, University of Anbar, Iraq. pp. 129.

Owaid MN. 2015 - Mineral elements content in two sources of Agaricus bisporus in Iraqi market. Journal of Advanced \& Applied Sciences. 3(2), 46-50.

Roberts JS, Teichert A, Mc Hugh TH. 2008 - Vitamin D2 Formation from Post-Harvest UV-B Treatment of Mushrooms (Agaricus bisporus) and Retention during Storage. J. Agaric. Food Chem. 56, 4541-4544.

Royse DJ. 2008 - Spawning to Casing in Commerical Mushroom Production. The Pennsylvania State University. University Park, PA 16802.

Sanchez JE, Royse DJ. 2008 - Scytalidium thermophilum Colonized Grain, Corn Cobs and Chopped Wheat Straw Substrates for the Production of A. bisporus. Bioresource Technology. 100(4), 1670-1674.

Sassine YN, Abdel-Mawgoud AMR, Ghora Y, Bohme M. 2007 - Effect of Different Mixtures with Waste Paper as Casing Soil on the Growth and Production of Mushroom (Agaricus bisporus). Australian Journal of Basic and Applied Sciences. 1(2), 96-104.

Schmidt O. 2006 - Wood and Tree Fungi, Biology, Damage, Protection and Use. Springer. Germany. pp. 334.

Simsek H, Baysal E, Colak M, Toker H, Yilmaz F. 2008 - Yield Response of Mushroom (Agaricus bisporus) on Wheat Straw and Waste Tea Leaves Based Composts Using Supplements of Some Locally Available Peats and their Mixture with Some Secondary Casing Materials. Afr. J. Biotechnol. 7(2), 88-94.

Stephens JM. 2003 - Mushroom - Agaricus bisporus (Lge.) Sing. Document is HS628, Institute of Food and Agricultural Sciences. University of Florida, Gainesville FL 32611.

Straatsma G, Gerrits JPG, Augustijn MPAM, Camp HJM et al. 1989 - Population Dynamics of Scytalidium thermophilum in Mushroom Compost and Stimulatory Effects on Growth Rate and Yield of Agaricus bisporus. J. Gen. Microbiol. 135, 751-759.

Tamberkar DH, Sonar TP, Khodke MV, Khante BS. 2006 - The novel antibacterial from two edible mushrooms: Agaricus bisporus and Pleurotus sajor caju. International Journal of Pharmacology. 2(5), 584-587.

USDA. 2011 - Mesopotamian Minute, Current News on Agriculture \& USDA in Iraq - Office of Agricultural Affairs, U.S. Embassy, Baghdad, 24 ${ }^{\text {th }}$ April, pp.1.

Wood D. 1976 - Primordium Formation in Axenic Cultures of A. bisporus (Lang). Sing. J. Gen. Microbiol. 95, 313-323.

Zarenejad F, Yakhchali B, Rasooli I. 2012 - Evaluation of indigenous potent mushroom growth promoting bacteria (MGPB) on Agaricus bisporus production. World J Microbiol Biotechnol. 28, 99-104.

Zervakis G, Philippoussis A. 2000 - Management of agro-industrial waste through the cultivation of edible mushrooms. Proceedings of the fourth European Waste Forum Innovation in Waste Management, Millan. pp. 87-90. 